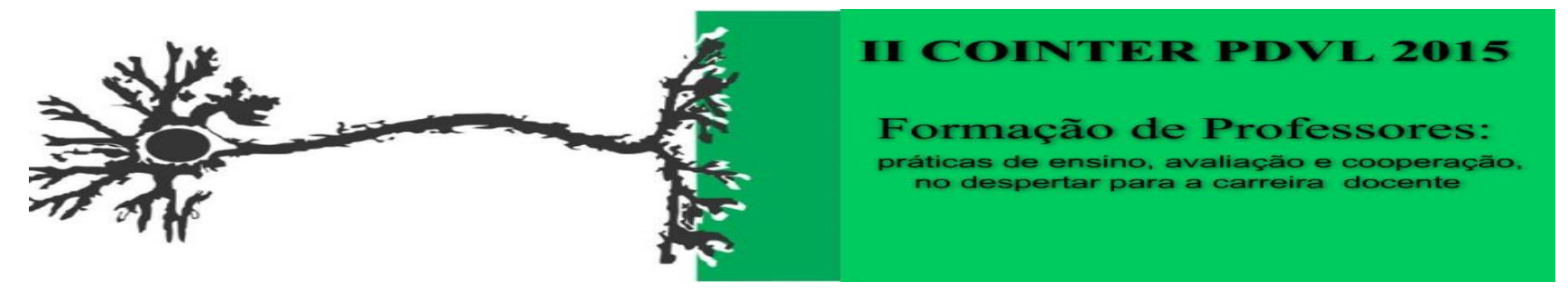

\title{
UTILIZAÇÃO DE VÍDEO E EXPERIMENTO NO PROCESSO DE ENSINO - APRENDIZAGEM SOBRE O TEMA MISTURAS
}

\section{Apresentação: Relato de Experiência}

\author{
Maria Aparecida Oliveira de Melo ${ }^{1}$; Ábina Profiro de Oliveira ${ }^{2}$; Rafael Ferreira da Silva ${ }^{3}$; \\ Priscilla do Carmo ${ }^{4}$
}

\section{Introdução}

Muito se fala em uma educação escolar que fuja do tradicionalismo de quadro e giz (ou piloto, quando há material deste tipo nas escolas). Até que ponto e de que forma uma aula que traz algo a ser chamado de "novo" tem efeito de facilitador no processo de ensino-aprendizagem? Adequar materiais disponíveis (TV, datashow, computador, etc.) com estratégias pedagógicas estimulam o aluno a prestar mais atenção e assim compreender melhor o assunto abordado. O presente trabalho tem por objetivo apresentar um relato de experiência, onde foi utilizado tanto vídeo quanto experimento em uma intervenção sobre o tema "misturas", realizada pelos integrantes do PIBID", estudantes da UFPE-CAV, com alunos do $9^{\circ}$ ano da Escola Municipal Dr. Ivo Queiroz Costa, no município de Vitória de Santo Antão, Pernambuco.

\section{Relato de Experiência}

É importante à adesão de recursos que possibilitem ao aluno a oportunidade e experiência de não apenas ouvir ou ver algo estagnado durante o momento das aulas. As mesmas não precisam acontecer só de modo tradicional, tendo recurso audiovisual presente na escola, se deve ter utilização deste meio na sala de aula, tendo em vista a possibilidade destes recursos, contribuírem para como processo de ensino/aprendizagem. "Os Meios de Comunicação operam imediatamente com o sensível, o concreto, principalmente, a imagem em movimento. Combinam a dimensão espacial com a cinestésica, onde o ritmo torna-se cada vez mais alucinante (como nos videoclips)" (MORAN, 1999, p.04). O aluno passa a ter

${ }^{1}$ Ciências Biológicas, UFPE, cidinhamelo1990@ hotmail.com

${ }^{2}$ Ciências Biológicas, UFPE, abina.por.firo@ hotmail.com

${ }^{3}$ Ciências Biológicas, UFPE, Rafaelsilvabiologia@ hotmail.com

${ }^{4}$ Pedagoga. Mestre em Educação - UFPE / CAA. Professora UFPE - CAV, priscillacarmopontes@ hotmail.com 1 Programa de Iniciação a Docência 
mais autonomia no seu aprendizado, tem a oportunidade de desfrutar momentos que os fazem abrir as portas da criatividade. "Cabe à escola estar preparada para receber os educandos de uma forma atrativa, permitindo uma boa interação entre professor, aluno e recursos oferecidos" (SANTOS 2010, p. 23).

Outra forma de inclusão metodológica é a experimentação como estratégia pedagógica. A fim de elucidar de uma forma mais real o "fazer" e assim reforçar o que foi visto com o vídeo para uma compreensão maior pelos alunos em relação ao tema em questão, é a experimentação que traz á tona e reforça o quanto deve ser dado à oportunidade, para que os mesmos possam ser autores na atividade proposta, e possam através desta, contemplarem o conhecimento adquirido por meio da sua participação ativa no processo.

Imagem 1: Atividade Experimental. Fonte: Própria
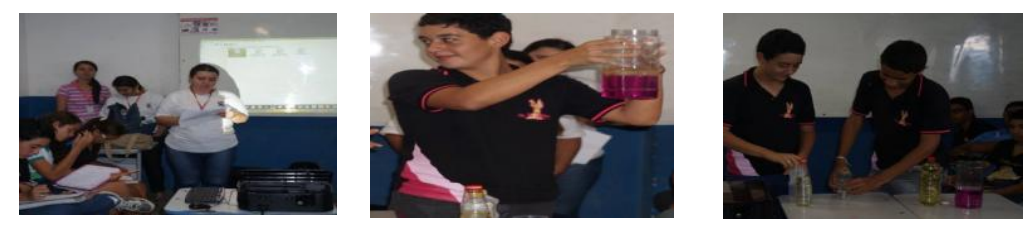

\section{Considerações}

A realização deste trabalho nos permitiu perceber o quão importante é trazer para a sala de aula, recursos que tornam a aula mais dinâmica e proveitosa, considerando a aprendizagem do aluno. Com isso, foi possível perceber quanto um vídeo, um experimento, ou qualquer outra atividade planejada pode mudar o comportamento, o interesse e o aprendizado dos alunos. Portanto, foi uma experiência proveitosa onde reforça as ações que devem ser postas em prática durante a licenciatura.

\section{Bibliografia}

MORAN, José Manuel. O uso das novas tecnologias da informação e da comunicação na EAD-uma leitura crítica dos meios. Palestra proferida no Programa TV Escola-Capacitação de Gestores, 1999.

SANTOS, P. C. A utilização de recursos audiovisuais no ensino de ciências: tendências entre 1997 e 2007. São Paulo, 2010. 